\title{
Local Green Power Supply Plants Based on Alcohol Regenerative Gas Turbines: Economic and Environmental Aspects
}

\author{
Oleksandr Cherednichenko ${ }^{1}\left(\mathbb{D}\right.$, Valerii Havrysh $^{2}{ }^{(1)}$, Vyacheslav Shebanin $^{3}$, \\ Antonina Kalinichenko ${ }^{4,5, * \mathbb{D}}$, Grzegorz Mentel ${ }^{6}(\mathbb{D})$ and Joanna Nakonieczny ${ }^{7}$ (D) \\ 1 Mechanical Engineering Institute, Admiral Makarov National University of Shipbuilding, 54025 Mykolayiv, \\ Ukraine; oleksandr.cherednichenko@nuos.edu.ua \\ 2 Department of Tractors and Agricultural Machines, Operating and Maintenance, \\ Mykolayiv National Agrarian University, 54020 Mykolayiv, Ukraine; havryshvi@mnau.edu.ua \\ 3 Rector, Mykolayiv National Agrarian University, 54020 Mykolayiv, Ukraine; rector@mnau.edu.ua \\ 4 Institute of Environmental Engineering and Biotechnology, University of Opole, 45-365 Opole, Poland \\ 5 Department of Information System and Technology, Poltava State Agrarian Academy, 36003 Poltava, Ukraine \\ 6 Department of Quantitative Methods, The Faculty of Management, Rzeszow University of Technology, \\ 35-959 Rzeszow, Poland; gmentel@prz.edu.pl \\ 7 Department of Finance, Banking and Accountancy, The Faculty of Management, \\ Rzeszow University of Technology, 35-959 Rzeszow, Poland; j.nakonieczny@prz.edu.pl \\ * Correspondence: akalinichenko@uni.opole.pl; Tel.: +48-787-321-587
}

Received: 1 March 2020; Accepted: 26 April 2020; Published: 1 May 2020

\begin{abstract}
Growing economies need green and renewable energy. Their financial development can reduce energy consumption (through energy-efficient technologies) and replace fossil fuels with renewable ones. Gas turbine engines are widely used in transport and industry. To improve their economic attractiveness and to reduce harmful emissions, including greenhouse gases, alternative fuels and waste heat recovery technologies can be used. A promising direction is the use of alcohol and thermo-chemical recuperation. The purpose of this study is to estimate the economic efficiency and carbon dioxide emissions of an alcohol-fueled regenerative gas turbine engine with thermo-chemical recuperation. The carbon dioxide emissions have been determined using engine efficiency, fuel properties, as well as life cycle analysis. The engine efficiency was maximized by varying the water/alcohol ratio. To evaluate steam fuel reforming for a certain engine, a conversion performance factor has been suggested. At the optimal water/methanol ratio of 3.075 this technology can increase efficiency by $4 \%$ and reduce tank-to-wake emission by $80 \%$. In the last 6 months of 2019 , methanol prices were promising for power and cogeneration plants in remote locations. The policy recommendation is that local authorities should pay attention to alcohol fuel and advanced turbines to curb the adverse effects of burning petroleum fuel on economic growth and the environment.
\end{abstract}

Keywords: price ratio; market prices; renewable energy; carbon dioxide emission

\section{Introduction}

The development of the global economy results in an increase in energy consumption and world trade [1]. To meet the energy requirements of society, gas turbine engines (GTE) are used worldwide for marine transport, aviation, land transport, power plants, etc. The primary challenges facing GTEs are improving their performance and reducing harmful emissions, including greenhouse gas (carbon dioxide) [2-4]. There are a lot of documents that promote green activity, e.g., the European Union Directive 2009/28/EC requires the use of biofuels in transport [5], the International Marine Organization 
strictly regulates harmful emissions from ships [6], the United Nations Intergovernmental Panel on Climate Change recommended a reduction of greenhouse gas emissions (GHG) by $50-85 \%$ from 2000 to 2050 [7]. The use of alternative fuels and electric transport can provide up to $80 \%$ of the projected carbon dioxide emission mitigation [8].

Biofuels can be used for transport (land, marine, and aviation) and energy sector [9]. The advantages of biofuels, including methanol and ethanol, are [10,11]:

- lower carbon dioxide emissions;

- $\quad$ energy diversification;

- strengthening energy security;

- slowing the depletion of fossil fuels.

Thermal engines can be powered by fuel blends (conventional and alternative) or a purely alternative fuel $[12,13]$. The application of alternative fuels is of significant interest [14]. The lower heating values of alcohol fuels (compared to petroleum ones) result in higher delivery to an engine $[15,16]$.

Around $60-70 \%$ of fuel energy injected into a gas turbine engine is transformed into exhaust gas energy. Therefore, waste heat recovery systems are of great importance for the above engines. There are several heat recovery methods, which increase the fuel economy of power plants and reduce harmful emissions [17-22]: thermo-electric energy conversion; organic Rankin cycle; and thermochemical technologies. A promising pathway to recover waste heat is to apply thermo-chemical recuperation-endothermic alcohol steam reforming, using exhaust gas energy [23,24]. It produces syngas (a mixture of hydrogen, carbon dioxide, and carbon monoxide). The energy value of syngas exceeds the energy content of the original fuel, therefore if a gas turbine engine is fed by syngas, it results in an increase in engine efficiency.

\section{Literature Review}

To improve gas turbine engine performance and environmental indicators, different technologies have been developed and used. There have been much research aiming to achieve the above. The regenerative gas turbine cycle has been studied by several scientists [25-27]. These studies show that efficiency of this cycle can be improved by optimizing a compressor pressure ratio and a degree of regeneration $[28,29]$. Researchers underlined that their thermal efficiency is improved if the turbine inlet temperature rises and the pressure ratio decreases [30].

An innovative combined cycle based on the integration of methanol decomposition and chemical-looping combustion was proposed and evaluated by Jin et al. [31]. As a result, engine power and efficiency improve. Pan et al. have found that the chemically recuperated gas turbine engine (where waste heat is used for steam fuel reforming) improved combustion and achieved higher thermal efficiency [32].

The National Advisory Committee for Aeronautics was one of the first institutions to use alcohol as a fuel for gas turbine engines. They studied a water-ethanol mixture. To produce water-ethanol vapor before entering the engine, exhaust gas energy was used [33]. The Juiz de Fora power plant (Brazil) was the first power plant in the world to be fed by hydrous ethanol. In 2010, General Electric Co. converted two 43.5 MW LM6000 gas turbine engines to burn ethanol [34].

Reliance Infrastructure Ltd. and GE Energy have carried out a bioethanol-naphtha blend field test on the Goa Power Plant (India). The gas turbine engine powered by biofuel showed excellent combustion performance and a decrease in harmful emissions [35].

The use of alcohol fuels is spurred by their clean burning, which is especially important for touristic regions. For example, in 2014, a 50 MW Pratt \& Whitney FT4C of the Eilat generation plant (Israel) was converted to methanol. The results of using methanol GTE are as follows: the heat rate is the same; NOx emission is reduced by $80-85 \%$; particulate and sulfur oxide emissions are almost zero [36]. Therefore, alcohol fuels may be an alternative in regions where there is no natural gas grid and there is stringent environmental regulation. 
Methanol and ethanol might be attractive fuels due to their competitive prices. Some methods help to make a rational decision based on market fuel prices and their physical properties [37].

Hydrogen is the best choice to reduce carbon dioxide emissions. However, the application of pure hydrogen is impossible due to its high production costs and safety issues. That is why this combustible gas can be produced by fuel steam reforming [38].

Alcohol steam reforming is in the spotlight of scientists. They studied the thermodynamics of the reforming process [39]. There are many studies concerning fuel cell systems combined with gas turbine engines [40-42]. Several studies were devoted to thermo-chemical recuperation for gas turbine engine applications [43-45]. Alcohol steam reformer features were studied [46-48]. Casanovas et al. analyzed the performance of an internal combustion engine powered by ethanol steam reforming products [49]. Tartakovsky et al. pointed out a possibility to improve engine efficiency by using thermo-chemical recuperation [50].

The exhaust gas temperature of simple cycle gas turbine engines exceeds $425^{\circ} \mathrm{C}$, which is enough for ethanol and methanol steam conversion [51-53]. In comparison, exhaust gas temperatures of regenerative gas turbine engines varies from 320 to $370{ }^{\circ} \mathrm{C}$. These engines have a relatively low pressure ratio. It does not exceed 10 [54-56]. However, the thermo-chemical recuperation of the above engines has not been examined enough, specifically an optimal water/alcohol ratio for achieving the maximum engine efficiency. There is also a research gap in the features of cogeneration plants based on these engines. The use of thermo-chemical recuperation results in an increase in the exhaust gas temperature. However, the efficiency of cogeneration plants based on alcohol regenerative engines with thermo-chemical recuperation did not come to the researchers' attention.

Previous studies did not include analysis of a gas turbine engine syngas supply system constraints and their impact on the performance of a thermo-chemical conversion of the primary fuel. Characteristics of gas turbine engines fed by-products of alcohol steam reforming have not been sufficiently investigated. The purpose of this study is to estimate the influence of thermo-chemical recuperation on economic and environmental indicators of regenerative gas turbines and combined heat and power plants. To achieve the above, this study is focused on the following: (i) the conversion efficiency of alcohol fuels; (ii) the optimal water/alcohol ratio to maximize the engine efficiency; (iii) well-to-wake carbon dioxide emissions; (iv) economic assessment of a regenerative gas turbine engine fueled by methanol; (v) the feasibility of using a cogeneration plant based on the engine under study.

\section{Materials and Methods}

The framework of this study is comprised of four stages. The first stage is the analysis of steam alcohol conversion for regenerative gas turbine engines. The second stage is the energy efficiency estimation of the regenerative gas turbine engine with thermo-chemical recuperation. In the third stage, well-to-wake carbon dioxide emissions for selected fuels were calculated. Then, the economic analysis of alcohol fuel was carried out.

A gas turbine engine is fed by syngas, which is a mixture of hydrogen and carbon monoxide. The thermodynamic properties of each component were determined using thermodynamic tables [57]. The thermo-chemical reformer is fed with alcohol (methanol or ethanol) and steam. The steam reforming excludes nitrogen (inert gas) from syngas, resulting in its lower heating value growth. To simplify our calculations, the following assumptions have been applied: all gases were considered as ideal gases; heat exchangers are ideal (no heat losses); there is a chemical equilibrium in the reformer.

\subsection{Steam Reforming}

The methanol steam reforming reaction is the following [58]

$$
\mathrm{CH}_{3} \mathrm{OH}+\mathrm{H}_{2} \mathrm{O} \rightarrow \mathrm{CO}_{2}+3 \mathrm{H}_{2}
$$


This reaction is endothermic. For the chemical reaction, a waste heat stream of the engine is used. It results in increasing the lower heating value of syngas compared with the initial liquid fuel. The lower heating value of syngas is around $20 \%$ higher than the methanol.

There is a similar steam reforming process for ethanol [58-60]

$$
\mathrm{C}_{2} \mathrm{H}_{5} \mathrm{OH}+3 \mathrm{H}_{2} \mathrm{O} \rightarrow 2 \mathrm{CO}_{2}+6 \mathrm{H}_{2}
$$

The above reaction occurs at a temperature of $550-600{ }^{\circ} \mathrm{C}$ [61]. Whereas methanol steam reaction needs a lower temperature-250-300 ${ }^{\circ} \mathrm{C}$ [48]. During the calculations, the complex reform process was simplified. In our mathematical model, we assumed that the steam reforming reaction proceeds completely. The mathematical model factors in the basic physical principles such as material balance, energy balance, mass, and heat transfer processes. The simulation was carried out using the Aspen Plus software.

\subsection{Fuels}

Methanol and ethanol were used in this study. Due to the low cetane number, pure alcoholic fuels cannot be used for diesel engines. They can be used for spark-ignition and gas turbine engines. Methanol and ethanol have a high heat of vaporization. The main difference between conventional and alcoholic fuels is their molecular composition: fossil fuels do not contain oxygen, whereas methanol has $50 \%$ oxygen, and ethanol- $34.8 \%$ by mass. Due to their simple chemical compositions, alcoholic fuels have a narrow distillation range (Table 1) [62-66].

Table 1. Physical and chemical properties of selected fuels.

\begin{tabular}{lcccc}
\hline \multicolumn{1}{c}{ Properties } & Unit & Diesel & Methanol & Ethanol \\
\hline Density & $\mathrm{kg} / \mathrm{m}^{3}$ & 840 & 796 & 789 \\
Boiling point & $\mathrm{K}$ & $453-643$ & 338 & 351 \\
Lower heating value & $\mathrm{MJ} / \mathrm{kg}$ & 42.5 & 19.67 & 26.9 \\
Stoichiometric air-fuel ratio & - & 14.6 & 6.45 & 9.06 \\
Heat of vaporization & $\mathrm{kJ} / \mathrm{kg}$ & 243 & 1100 & 840 \\
Viscosity & $\mathrm{cSt}$ & 4.59 & 0.65 & 1.52 \\
Auto-ignition temperature & $\mathrm{K}$ & 503 & 736 & 698 \\
Carbon content by mass & $\%$ & 85 & 37.5 & 52.2 \\
Hydrogen content by mass & $\%$ & 15 & 12.5 & 13 \\
Oxygen content by mass & $\%$ & 0 & 50 & 34.8 \\
Specific carbon dioxide emission & $\mathrm{g} / \mathrm{MJ}$ & 73.33 & 68.44 & 70.99 \\
\hline
\end{tabular}

\subsection{Efficiency Indicators}

The following efficiency indicators were used:

- lower heating values of primary alcohol fuels and syngas;

- $\quad$ syngas to alcohol lower heating value ratio;

- energy efficiency of conversion;

- gas turbine engine efficiency.

The energy efficiency of conversion is the ratio of the increase of syngas energy content compared to the original fuel. To calculate the above, we propose the expression

$$
\eta_{a}=\frac{\frac{G_{s}}{G_{a}} \cdot L H V_{s}-L H V_{a}}{L H V_{a}},
$$

where $G_{a}$ is the alcohol fuel consumption, $\mathrm{kg} / \mathrm{s} ; G_{s}$ is the syngas consumption, $\mathrm{kg} / \mathrm{s} ; L H V_{a}$ is the lower heating value of alcohol fuel, $\mathrm{kJ} / \mathrm{kg} ; L H V_{s}$ is the lower heating value of syngas, $\mathrm{kJ} / \mathrm{kg}$. 
To assess the effectiveness of waste heat thermo-chemical alcohol regeneration technology, an efficiency indicator was suggested. It is the ratio of mechanical power on the engine to fuel energy

$$
\eta_{a}=(P e-P p) \cdot\left(G_{a} \cdot L H V_{a}\right)^{-1},
$$

where $P e$ is the mechanical power on the output shaft of a gas turbine engine, $\mathrm{kW} ; P p$ is the power consumed by water and alcohol fuel pumps, $\mathrm{kW}$.

This indicator is compared with the efficiency of the engine without thermo-chemical fuel regeneration.

\subsection{Carbon Dioxide Emission Indicator}

We propose to determine specific carbon dioxide emissions. Its value depends on the engine efficiency, the lower heating value of fuel and carbon content in the fuel

$$
C D E=\frac{3600}{\eta \cdot L H V} \cdot C C \cdot \frac{11}{3}, \mathrm{~kg} / \mathrm{kWh},
$$

where $\eta$ is the engine efficiency; $C C$ is the carbon content in the fuel, $\mathrm{kg} / \mathrm{kg}$.

This relationship is true if all of the carbon reacts with oxygen to form carbon dioxide. Therefore, to reduce carbon dioxide emissions, the engine efficiency should be increased and the carbon content should be decreased. In our calculation, we factored in emissions from fuel supply pathways-well-to-wake (WTW) emissions.

\subsection{Economic Assessment}

To estimate the efficiency of the utilization of different fuels, the fuel energy cost, and the energy cost for useful work were applied [66]. The energy cost was determined as

$$
E C=\frac{F p r}{L H V_{f}}, \mathrm{USD} / \mathrm{GJ},
$$

where $\mathrm{Fpr}$ is the price of fuel, $\mathrm{USD} / \mathrm{t} ; L H V_{f}$ is the lower heat value of the fuel, $\mathrm{MJ} / \mathrm{kg}$.

The energy cost for useful work was calculated as

$$
E C U W=\frac{F p r}{\eta \cdot L H V_{f}}, \mathrm{USD} / \mathrm{GJ}
$$

The same per MWh is

$$
\mathrm{ECUW}=\frac{F p r}{3.6 \cdot \eta \cdot L H V_{f}}, \mathrm{USD} / \mathrm{MWh} \text {. }
$$

For economic analysis, marine gas oil (MGO) and methanol historical prices from January 2017 were used. The global average Bunker prices for MGO are available online on the Bunker website. Official prices of Methanex (the world's largest producer of methanol) were applied for this study.

\section{Results}

\subsection{Steam Alcohol Conversion}

Currently, leading thermal engine manufacturers have adapted them to run on alternative fuels such as natural gas, liquefied petroleum gas, alcohols, etc. That resulted in an improvement of economic and environmental indicators. However, the disadvantages of gaseous fuels are the following: high-pressure storage; considerable energy consumption of gas compressor (up to $5 \%$ of engine power) [67]. 
Although alcohol fuels (methanol and ethanol) are low carbon ones, their use is hindered by their low energy density. To improve their energy and ecological characteristics, alcohol steam conversion can be used.

The available exhaust gas temperature of modern gas turbine engines ranges from 620 to $850 \mathrm{~K}$. It makes possible the partial conversion of hydrocarbon fuels (natural gas, diesel fuel, butane, propane, ethane, etc.) as well as effective alcohol fuel (methanol and ethanol) conversion $[18,19]$. The study of the efficient methanol steam conversion is of particular interest. The reason is that methanol is the most promising alcohol fuel for gas turbines. Its thermo-chemical conversion may be done by a waste heat recovery system of any gas turbine engine.

Hydrocarbon fuel steam conversion is an endothermic reaction and comprises steam reforming (SR), decomposition (D), and as well as water-gas (WGS) exothermic reaction. For steam methanol conversion, the reactions are [17]

$$
\begin{gathered}
\mathrm{CH}_{3} \mathrm{OH} \leftrightarrow 2 \mathrm{H}_{2}+\mathrm{CO} \Delta \mathrm{H}=91 \mathrm{~kJ} / \mathrm{mol}(\mathrm{D}) \\
\mathrm{CO}+\mathrm{H}_{2} \mathrm{O} \leftrightarrow \mathrm{H}_{2}+\mathrm{CO}_{2} \Delta \mathrm{H}=-41 \mathrm{~kJ} / \mathrm{mol}(\mathrm{WGS}) \\
\mathrm{CH}_{3} \mathrm{OH}+\mathrm{H}_{2} \mathrm{O} \leftrightarrow \mathrm{CO}_{2}+3 \mathrm{H}_{2} \Delta \mathrm{H}=50 \mathrm{~kJ} / \mathrm{mol}(\mathrm{SR}) .
\end{gathered}
$$

There are several studies of modeling methanol steam reforming processes based on the Gibbs free energy minimization method $[17,38,50,68,69]$. It was found that a complete methanol conversion needs a temperature range from 573 to $623 \mathrm{~K}$. The temperature increase results in a reduction of the hydrogen and carbon monoxide output. An increase of the steam/methanol ratio above the optimum value also reduces hydrogen and carbon monoxide output. A comparison of mathematical modeling and experiments allowed researchers to find corrective functions that factor in nonequilibrium reforming and the influence of the catalyst [50]. The steam methanol conversion (at atmospheric pressure) has the maximum energy efficiency under the following conditions: the temperature range from 570 to $580 \mathrm{~K}$; the water/methanol ratio is $1.3(\mathrm{~mol} / \mathrm{mol})$ [38].

The gaseous fuel supply pressure in the gas turbine engine ranges from 2 to $3 \mathrm{MPa}$. Regenerative engines can use lower gaseous fuel pressure. To clarify the effect of the process pressure on the conversion efficiency, mathematical modeling of the methanol steam reforming at high pressure was carried out (Figure 1). The model shows that to ensure the high efficiency of thermo-chemical conversion at high pressure, the temperature must be increased. This coincides with previous studies [68].

At the same time, gas turbine engine manufacturers claim that it is possible to run on high hydrogen content gaseous fuels. According to tests, engines show stable operation with a hydrogen content of up to $60 \%$ volume [70-73].

The syngas composition depends on the temperature and pressure. It influences its lower heating value. To estimate the conversion efficiency, we suggest using a new indicator-the conversion performance factor

$$
C P F=\frac{G_{s t p} \cdot L H V_{s t p}}{G_{s 0} \cdot L H V_{s 0}}
$$

where $G_{s 0}$ is the syngas mass from one $\mathrm{kg}$ of alcohol fuel for an ideal process, $\mathrm{kg}$; $L H V_{s 0}$ is the lower heating value of syngas for an ideal process, $\mathrm{MJ} / \mathrm{kg}$; $G_{s t p}$ is the syngas mass from one $\mathrm{kg}$ of alcohol fuel for an actual process, $\mathrm{kg}$; $L H V_{\text {stp }}$ is the lower heating value of syngas for an actual process, $\mathrm{MJ} / \mathrm{kg}$.

With reaction (1), the resulting syngas has a higher energy content compared to the original methanol. Its energy content is $23.97 \mathrm{MJ}$ or $21.35 \%$ higher. This is correct for the ideal reaction. In actual conditions, the above energy content cannot be achieved. Therefore, the conversion of chemical performance factor is less than 1. 


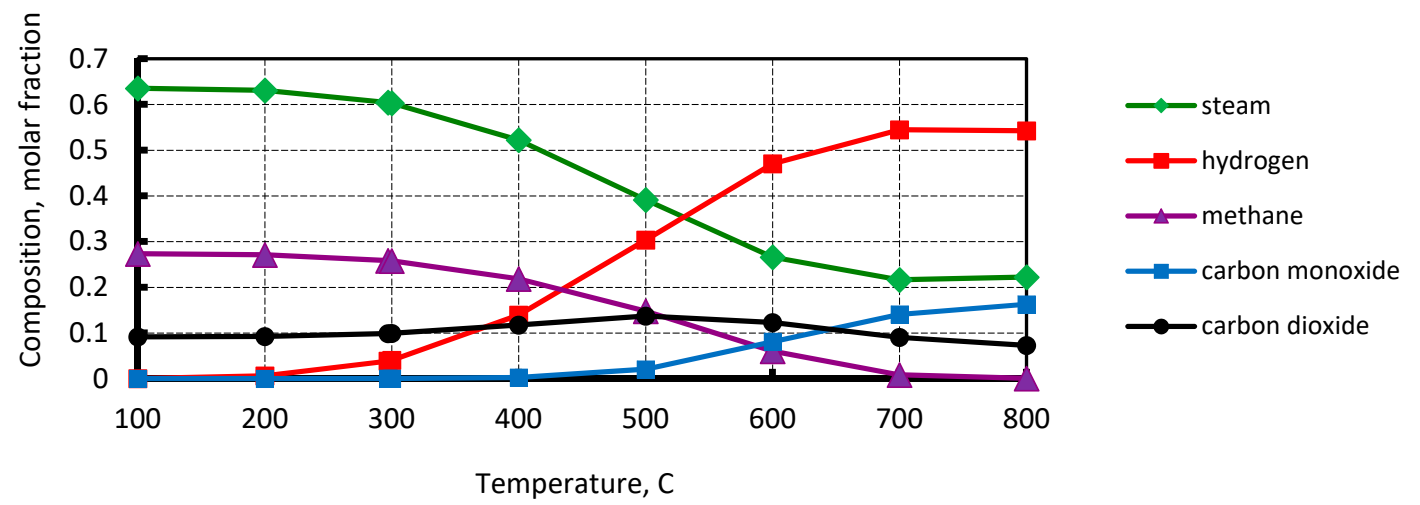

(a)

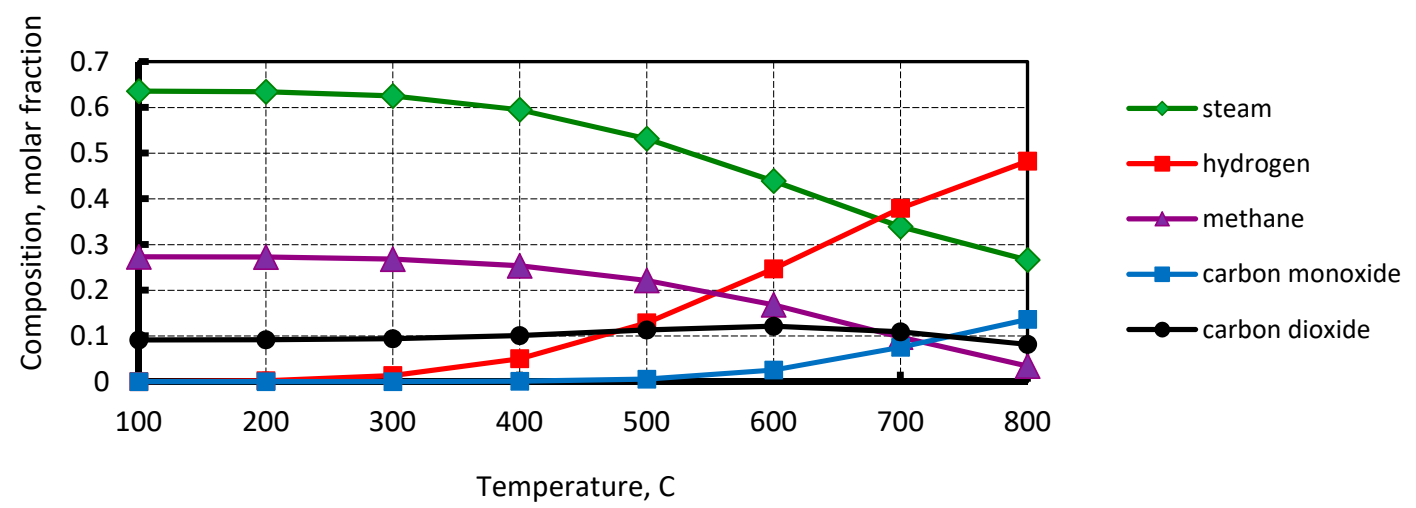

(b)

Figure 1. Component composition of the methanol steam reforming versus temperature and pressure: (a) $P=0.1 \mathrm{MPa}$; (b) $P=1.0 \mathrm{MPa}$.

\subsection{Regenerative Engine}

Effective methanol steam reforming does not need high temperature. It varies from 570 to $620 \mathrm{~K}$. Previous studies have revealed a promising scheme for a regenerative gas turbine engine. That is a sequential placement of a turbo-compressor unit (TC), a regenerator (R), and a thermo-chemical reactor or reformer (TCR) [18,19]. The designation of this scheme is TC-R-TCR. Due to the low-pressure ratio in the regenerative gas turbine, the effect of pressure on the efficiency of steam methanol-reforming is negligible. In this scheme, a gas-steam mixture (after the reactor) with a high temperature is supplied to the combustor like in the STIG cycle.

The current study was performed based on the regenerative gas turbine engine UGT3200R [56]. The engine is designed to drive an electric generator and can be used as part of a marine power plant with electric propulsion. The degree of regeneration is chosen according to the prototype and is as close to the maximum as possible since the more it is increased, the more significant is growth in the heat exchange surface. The turbine inlet temperature is also assumed according to the prototype.

The mathematical model of the gas-turbine block is based on aggregate calculations of the regenerative gas turbine engine. It factors in the total pressure drop in all elements of the engine and the use of air for cooling the turbine blades. To determine the hydraulic resistances, a simulation of heat exchangers was carried out. The model of the combustor is based on a combined chemical and phase equilibrium. To determine the component composition, Gibbs free energy is minimized for the reaction products $[74,75]$. The heat consumption of the exhaust gases required for alcohol conversion is determined by the heat balance of the thermo-chemical reactor. 
Initial data for simulation is presented in Table 2. Ambient air parameters were accepted according to ISO 19859: 2016. The engine efficiency was calculated according to Formula (4).

Table 2. Parameters of based regenerative gas turbine engine [56].

\begin{tabular}{lcc}
\hline \multicolumn{1}{c}{ Parameters } & Unit & Value \\
\hline Output & $\mathrm{MW}$ & 3.4 \\
Air-flow & $\mathrm{kg} / \mathrm{s}$ & 16 \\
Pressure ratio & - & 7 \\
Heat exchange thermal ratio & - & 0.85 \\
Exhaust gas temperature & $\mathrm{K}$ & 600 \\
Turbine inlet temperature & $\mathrm{K}$ & 1270 \\
Initial temperature & $\mathrm{K}$ & 288 \\
\hline
\end{tabular}

It is possible to use a two structural schemes for integrating a thermochemical reactor into a gas turbine engine. In the first scheme, the reaction proceeds at atmospheric pressure. The produced syngas is subjected to hydration and compression for feeding into the combustor. In the second scheme, there is a high-pressure reaction. Previous studies have shown that the second scheme is energetically more preferable [76].

A feature of our engine cycle model is that the thermo-chemical fuel conversion occurs at an elevated pressure (from 2 to $3 \mathrm{MPa}$ ). This solution allows for achieving the following advantages. Firstly, the syngas compressor is excluded from the fuel system. This simplifies the fuel system and reduces the energy consumption for compressing a fuel gas. Available methanol and water pumps consume significantly less energy by themselves. Secondly, thermal energy losses are reduced compared to low-pressure conversion. This is a consequence of the exclusion of the synthesis gas compression process. In the case of conversion at low pressure, the synthesis gas must be cooled before it is compressed. Moreover, the loss of steam condensation is excluded.

A simplified calculation scheme of a steam thermo-chemical recuperation-based alcohol regenerative gas turbine engine is presented in Figure 2. The layout of the thermo-chemical recuperation of the regenerative gas turbine engine includes specific components such as a water supply pump, an alcohol supply pump, a steam generator, and a reformer. The main components of the engines are a turbine, a compressor, a combustor, and a regenerator. The parameters of the working fluids in the control points are presented in Table 3. In our mathematical model, it was assumed that the difference between the exhaust gas temperature and the working fluid temperature (thermo-chemical reformer) is not less than $15 \mathrm{~K}$. The working pressure in the thermo-chemical reformer exceeds the pressure after the air compressor and is $2 \mathrm{MPa}$.

Table 3. Parameters of working fluids of the gas turbine plant with thermo-chemical reforming of methanol (maximum energy efficiency).

\begin{tabular}{cccc}
\hline Points & Temperature, $\mathbf{K}$ & Pressure, MPa & Mass Flow, kg/s \\
\hline 1 & 288 & 0.101 & 16.00 \\
2 & 1251 & 0.672 & 12.17 \\
3 & 584 & 1.000 & 1.09 \\
4 & 451 & 0.101 & 17.09 \\
\hline
\end{tabular}




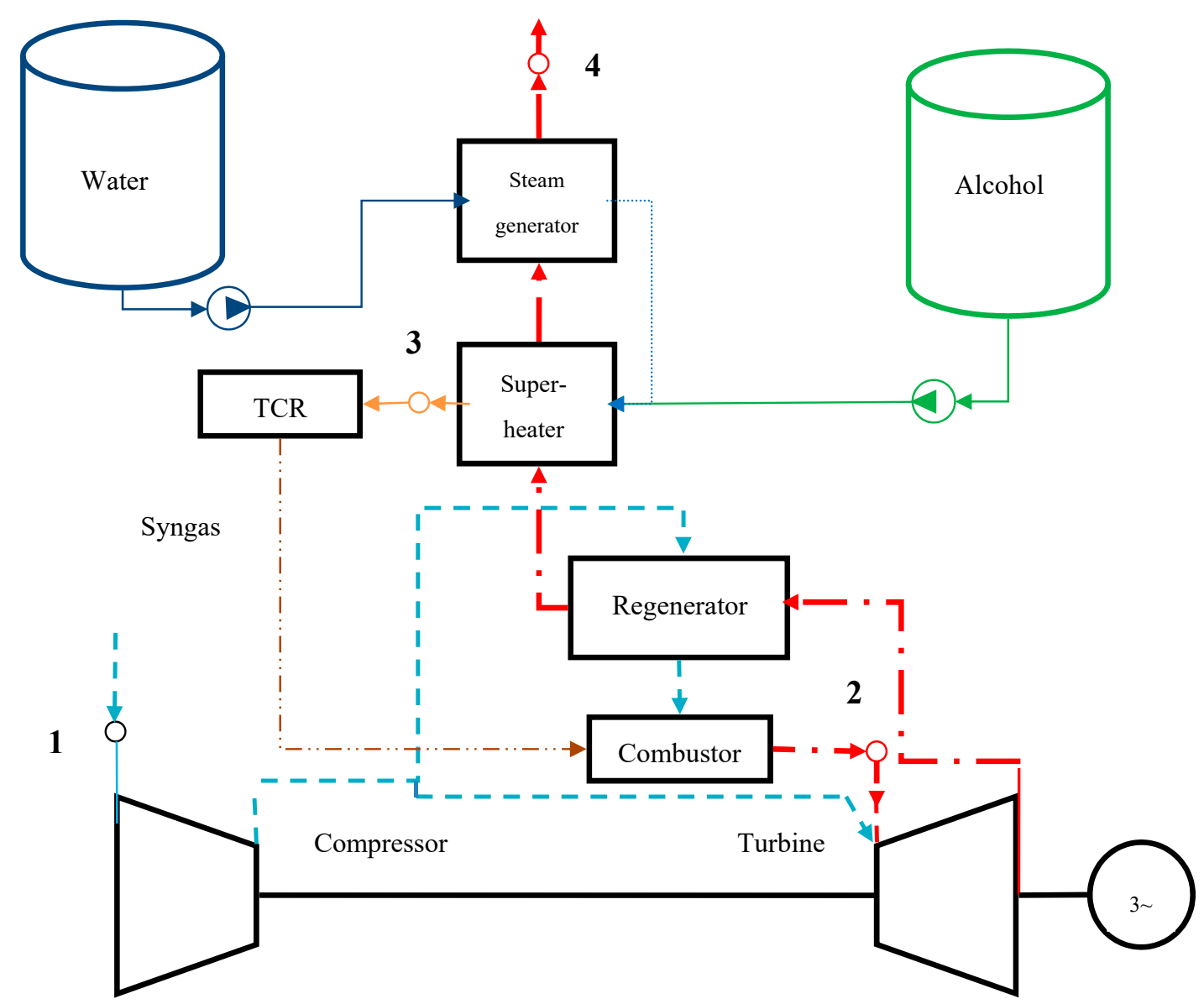

Figure 2. Simplified scheme of a regenerative gas turbine plant with methanol thermo-chemical conversion.

The optimization of the cycle was carried out by varying water/methanol mass ratio and a gas temperature after the regenerator. The water/methanol mass ratio ranged from 0.2 to 1.0. The upper value of the range was limited by the exhaust gas temperature. The regenerator outlet temperature ranged from 580 to $620 \mathrm{~K}$. The range was determined by the minimum acceptable temperature for the thermo-chemical reformer and the given degree of regeneration.

The engine efficiency with steam methanol conversion is described by a parabola (Figure 3). It has an extremum (maximum) point at a water/methanol ratio of 3.075. It is the optimal ratio for proposed scheme. Under these conditions, the volumetric composition of syngas is as follows, \%: hydrogen-58.07; steam-19.61; carbon dioxide-19.34; methanol-2.95; carbon monoxide-0.03. Its lower heating value is $11.3 \mathrm{MJ} / \mathrm{kg}$. As a result of the thermo-chemical conversion, $1 \mathrm{~kg}$ of methanol is transformed into $1.94 \mathrm{~kg}$ of synthesis gas. Its energy content is $11.45 \%$ higher than the original methanol one. It means that the conversion performance factor is equal to 0.918 .

A mathematical examination of the process showed that the efficiency increases by $4 \%$ compared to the base engine running on methanol. The thermo-chemical recuperation allows the engine to have the exhaust gas energy utilization factor of 0.478 [77].

According to our calculations, if the exhaust gas temperature is less than $477^{\circ} \mathrm{C}$, the energy efficiency of ethanol steam conversion is negative (Figure 4). The further increase of the water/ethanol ratio does not affect the energy efficiency. Therefore, ethanol steam recuperation for regenerative gas turbine engines is not acceptable.

The increase was defined as the ratio of the difference in heat released during combustion synthesis gas obtained by steam conversion of $1 \mathrm{~kg}$ of ethanol and heat released during combustion of every $1 \mathrm{~kg}$ of ethanol. 


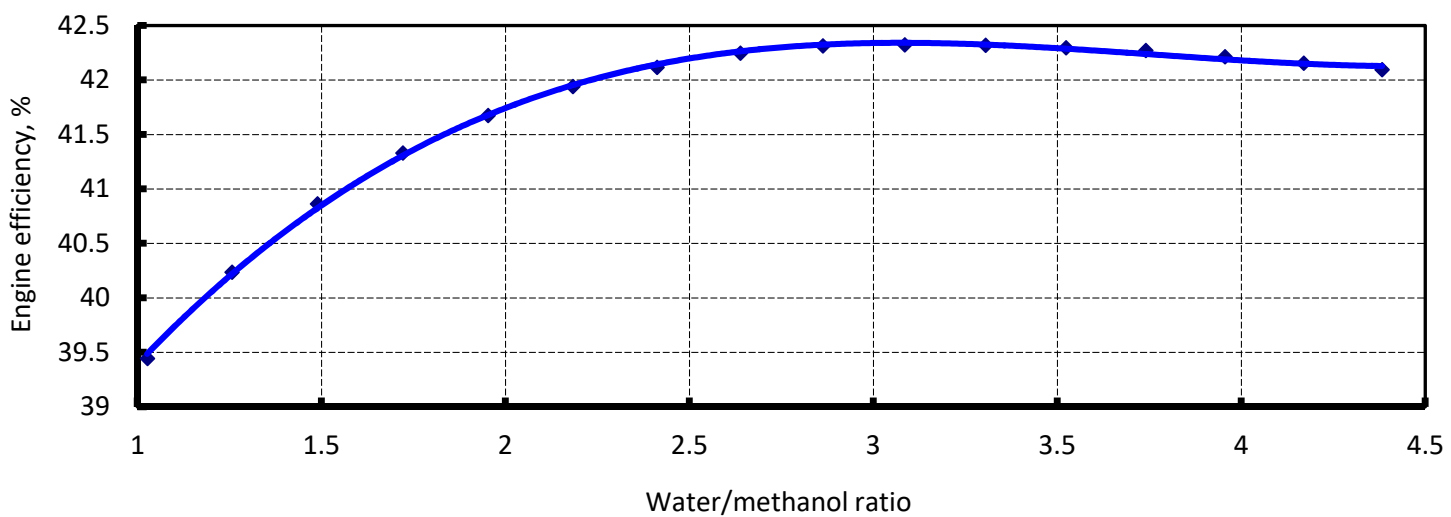

Figure 3. Engine efficiency of steam methanol conversion versus a water/methanol ratio.

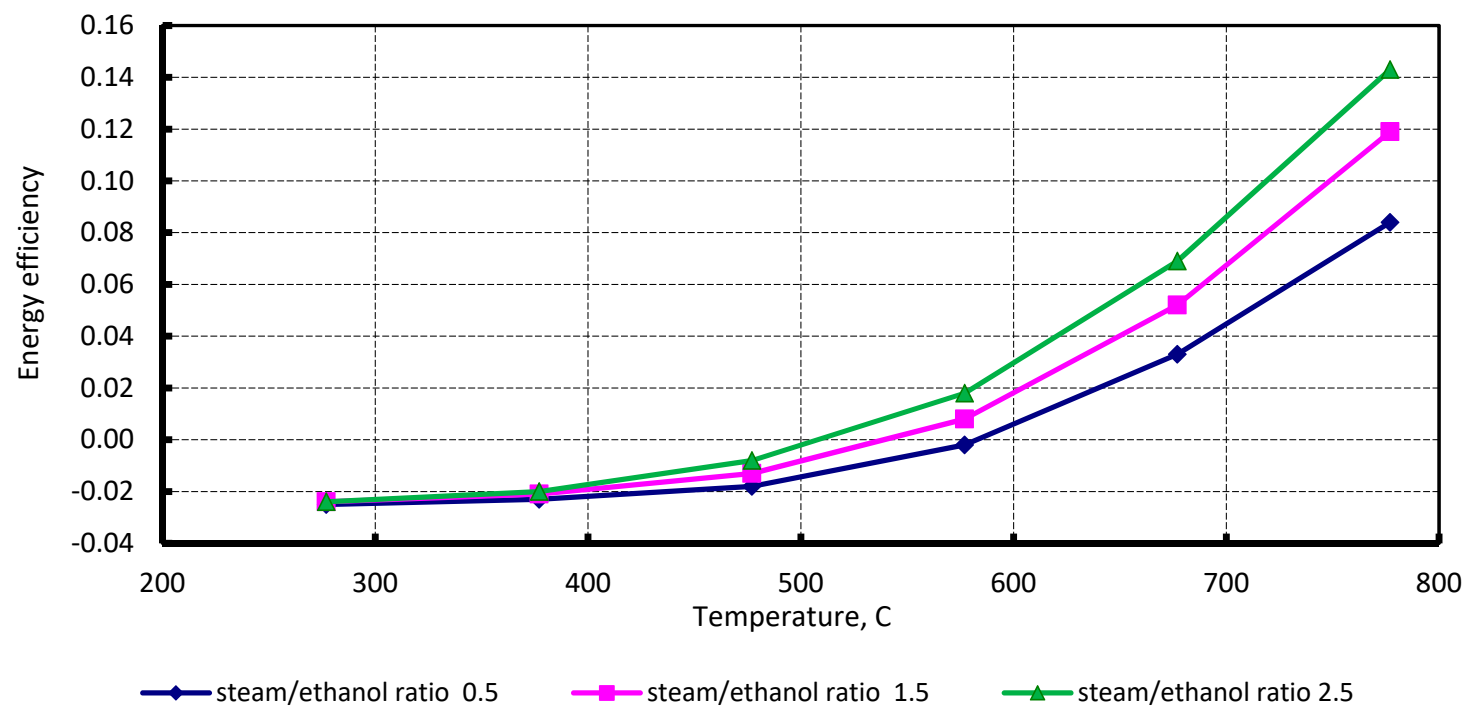

Figure 4. Energy efficiency of steam ethanol conversion versus a water/ethanol ratio and temperature.

\subsection{Carbon Dioxide Emission}

Tank-to-wake carbon dioxide emissions calculated according to the Formula (2) are presented in Figure 5. However, the results do not factor in well-to-tank (WTT) emissions for different fuels. WTT carbon dioxide emissions for diesel fuel vary from 6.7 to $24 \mathrm{~g} \mathrm{CO}_{2}$-eq/MJ [78] or from 284 to $1020 \mathrm{~g}$ $\mathrm{CO}_{2}$-eq $/ \mathrm{kg}$. Well-to-tank $\mathrm{GHG}$ emissions for natural gas range from 18.6 to $26.4 \mathrm{~g} \mathrm{CO}_{2}$-eq $/ \mathrm{MJ}$ [79-81] or from 909.5 to $1290.9 \mathrm{~g} \mathrm{CO}_{2}$-eq $/ \mathrm{kg}$.

WTT for methanol depends on technology applied and feedstock. Its value varies from $(-0.898 \mathrm{~kg}$ $\mathrm{CO}_{2}-\mathrm{eq} / \mathrm{kg}$ ) for biomass and renewable electricity to $2.965 \mathrm{~kg} \mathrm{CO}-\mathrm{eq} / \mathrm{kg}$ for coal [82]. The GHG emissions for bioethanol production range from -13.1 to $-55.5 \mathrm{~g} \mathrm{CO}_{2}$-eq/MJ [83] or from -352 to $-1493 \mathrm{~g} \mathrm{CO}_{2}$-eq $/ \mathrm{kg}$.

We suggest determining the total carbon dioxide emissions by the formula

$$
W T W=\frac{3600}{\eta \cdot L H V} \cdot\left(C C \cdot \frac{11}{3}+W T T e\right), \mathrm{kg} / \mathrm{kWh},
$$

where WTTe is the well-to-tank carbon dioxide emissions for any fuel, $\mathrm{kg} \mathrm{CO}_{2}-\mathrm{eq} / \mathrm{kg}$.

The results of our calculations are presented in Figure 5. The ethanol application has the best result. Steam methanol thermal recuperation has carbon dioxide emissions close to the burning of ethanol in gas turbines. 


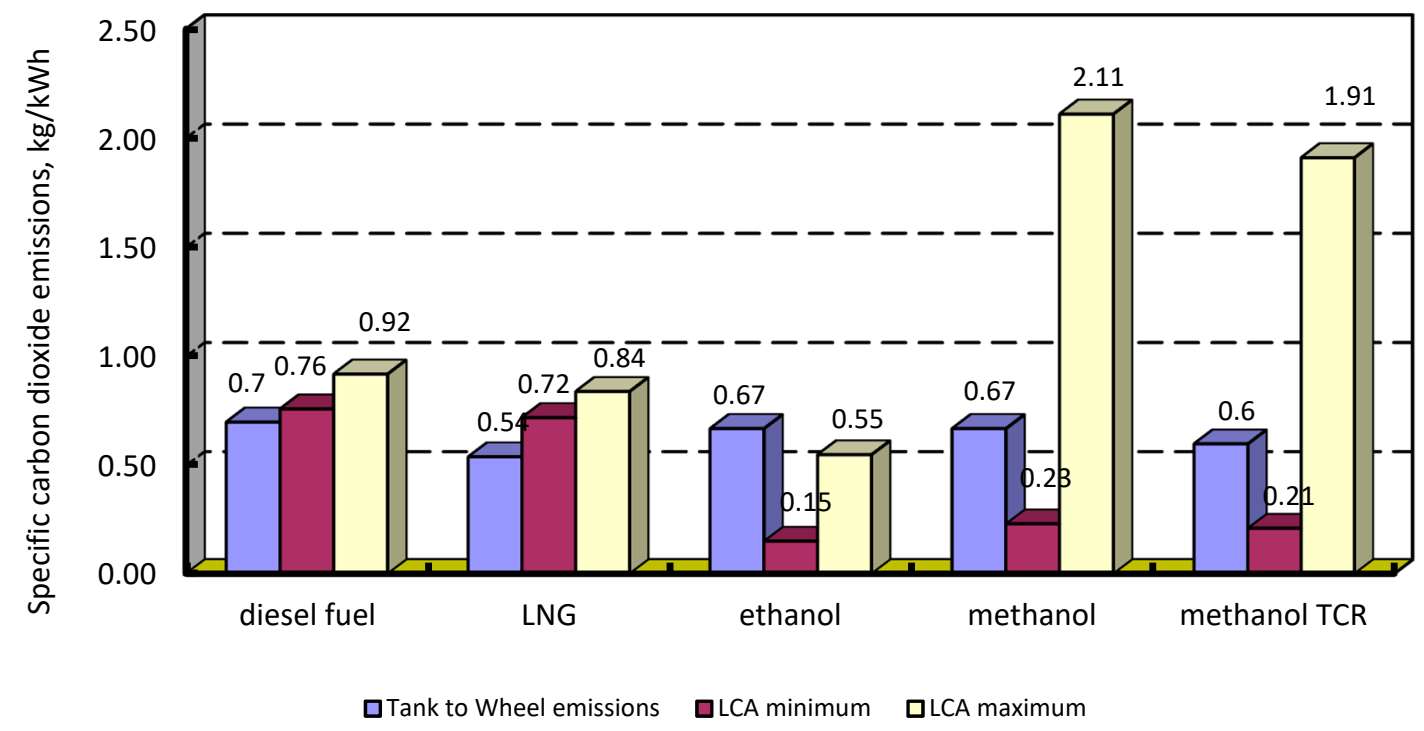

Figure 5. Specific carbon dioxide emissions.

\subsection{Economic Assessment}

The following target markets are recommended for methanol as a fuel: ship power plants (to reduce harmful emissions); recreation areas; power and combined heat and power plants in the areas where there is a deficit of cheap conventional fuels (natural gas, diesel fuel, etc.) [84,85]. Hereafter, we considered the economic efficiency of methanol application as a fuel.

An economic analysis was fulfilled to compare marine gas oil (MGO) and methanol. The global average bunker prices [86] and Mathenex methanol prices $[87,88]$ were used (Figure 6). Due to these fuels having quite different physical properties, their energy costs are analyzed (Figure 7). Since September 2019, energy cost of methanol has been lower compared to MGO. The same situation is for the energy costs for useful work (Figure 8).

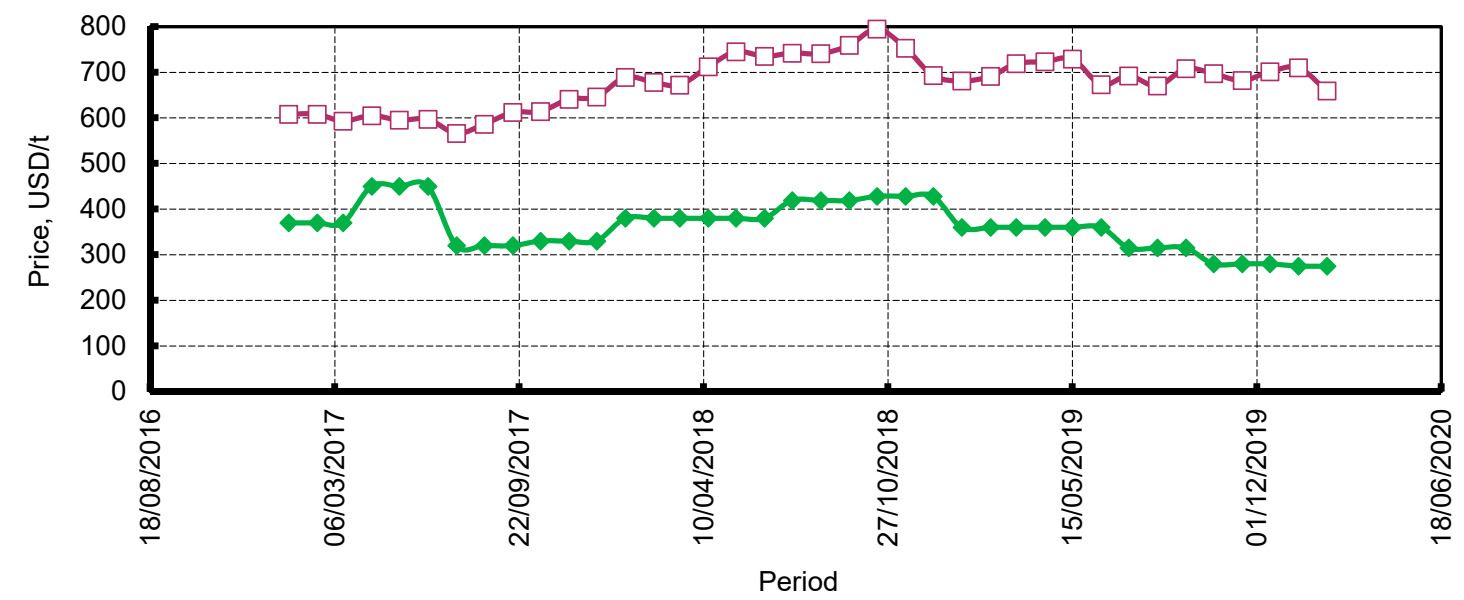

$\smile$ methanol $\square-\mathrm{MGO}$

Figure 6. Selected fuel prices. 


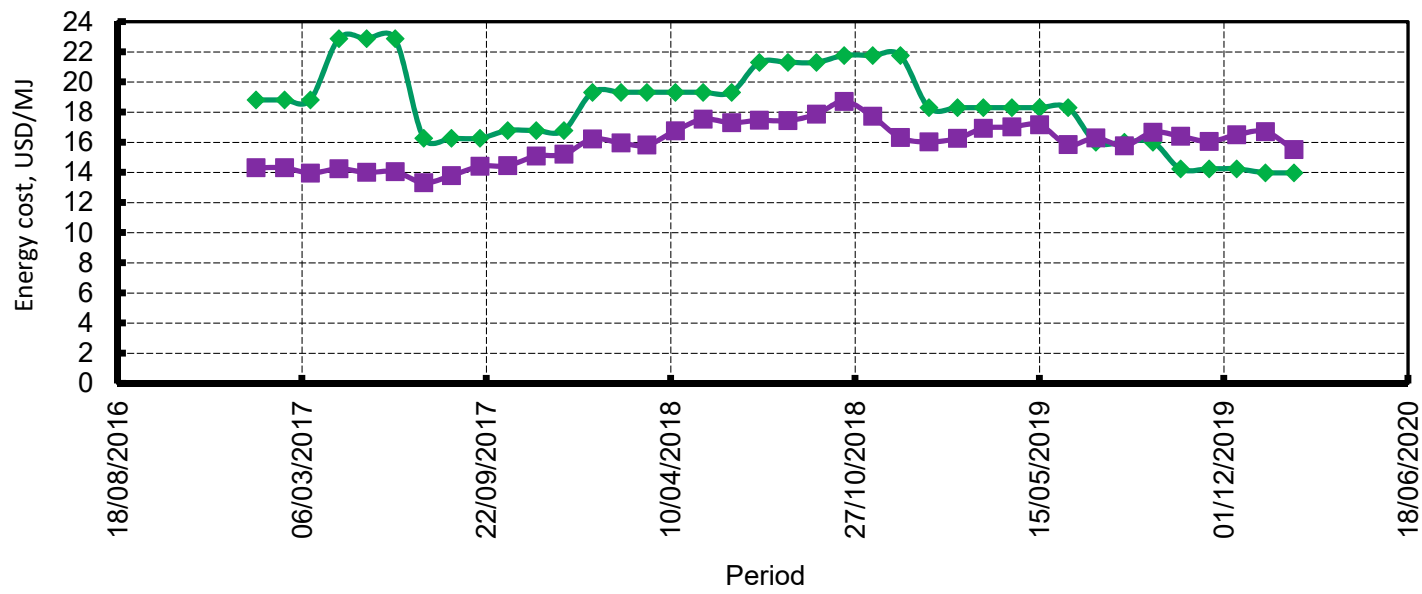

$\longrightarrow$ methanol $\rightarrow$ MGO

Figure 7. Energy cost.

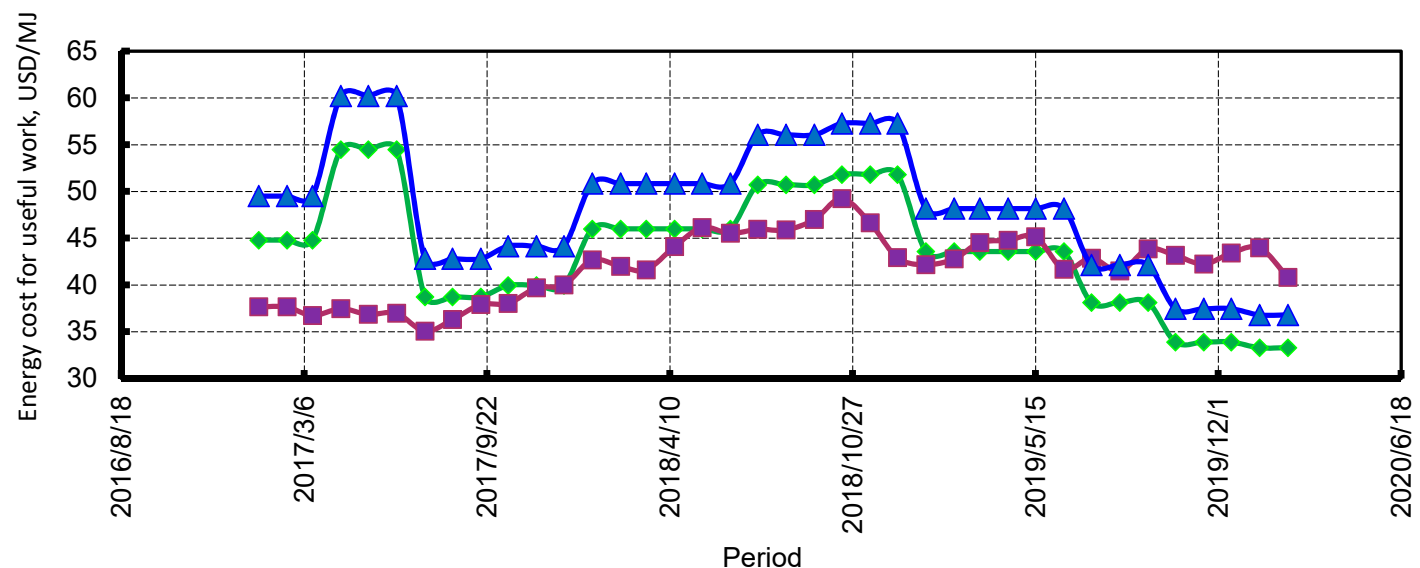

$\longrightarrow$ methanol, efficiency - $42 \% \longrightarrow$ methanol, efficiency - $38 \%$

Figure 8. Energy cost for useful work.

Electricity production from fuel bought for a unit of money is

$$
W_{m}=\frac{1000 \cdot \eta \cdot L H V}{3600 \cdot F p r}=\frac{\eta \cdot L H V}{3.6 \cdot F p r}, \mathrm{kWh} / \mathrm{USD} .
$$

The calculations were made for prices as of December 2019. The use of methanol and thermo-chemical recuperation has the best results (Figure 9).

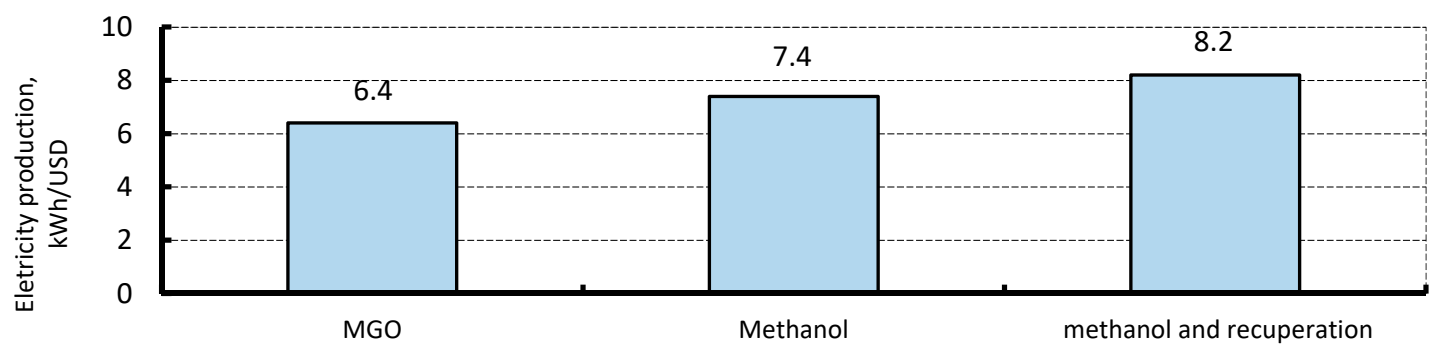

Figure 9. Electricity production for a unit of money. 
To facilitate decision making for potential consumers, an alternative to the conventional fuel prices ratio has been recommended $[37,66]$. The equilibrium point factors in their lower heating values and the engine efficiency is calculated by the formula

$$
P F R_{0}=\frac{F p r_{a}}{F p r_{c}}=\frac{L H V_{a} \cdot \eta_{a}}{L H V_{c} \cdot \eta_{c}}
$$

where $L H V_{a}$ is the lower heating value of alternative fuel, $\mathrm{kJ} / \mathrm{kg} ; L H V_{c}$ is the lower heating value of conventional fuel, $\mathrm{kJ} / \mathrm{kg} ; \eta_{a}$ is the engine efficiency when the alternative fuel is used;. $\eta_{c}$ is the engine efficiency when the conventional fuel is used.

The alternative fuel is acceptable if the actual ratio is less than $P F R_{0}$. Since June 2019 for a regenerative gas turbine engine with thermo-chemical recuperation and from July 2019 for a conventional regenerative gas turbine engine, the actual methanol/MGO price ratios are less than the equilibrium point (Figure 10). Therefore, methanol may be considered as a competitive alternative to liquid petroleum fuels.

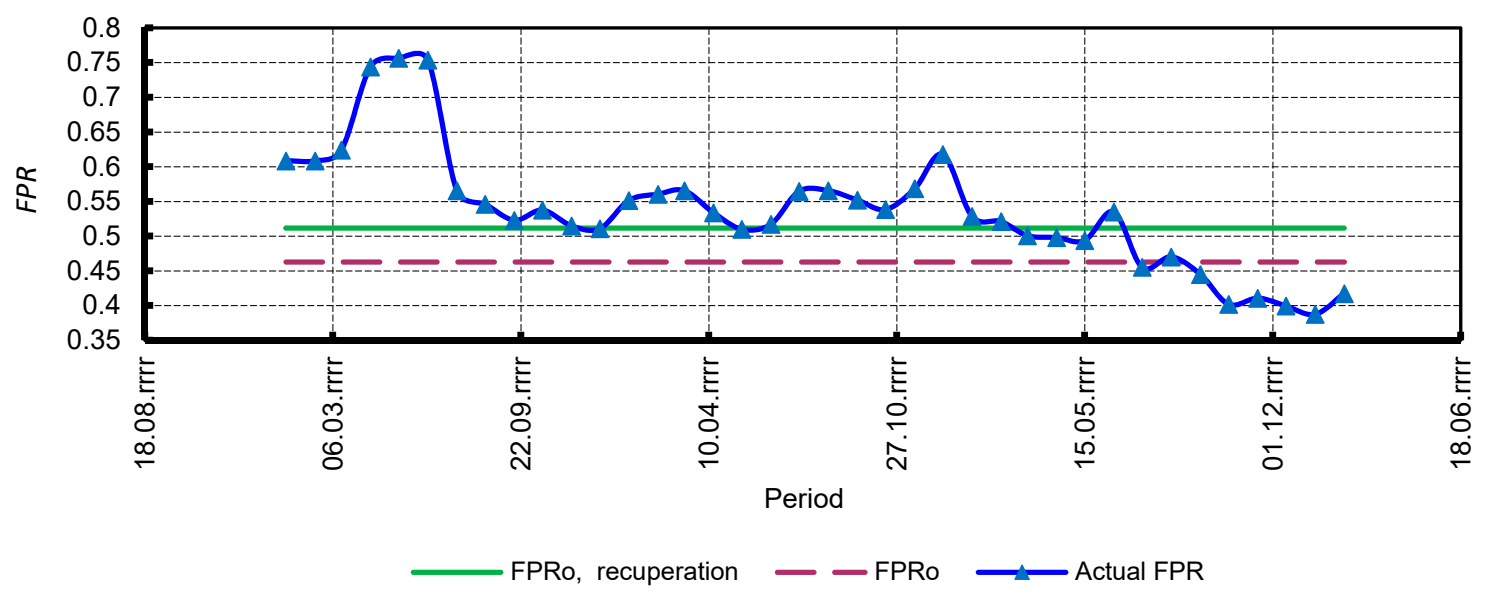

Figure 10. Methanol/MGO prices ratio.

\subsection{Combined Heat and Power Plant}

An alcohol regenerative gas turbine with thermo-chemical recuperation may be a base of a combined heat and power plant. The produced thermal power can be used for heat supply systems. Having sold this thermal energy, stakeholders can increase their total income. The thermal power is determined by three primary factors: the exhaust gas flow; the exhaust gas temperature; and, the outlet temperature of the exhaust gas boiler.

Methanol does not contain sulfur, resulting in a lower outlet temperature compared to petroleum fuels. In this study, three options of CHP were analyzed. They differ by the type of fuel and the use of thermo-chemical recuperation. The first option is the CHP based on a regenerative gas turbine engine fueled by MGO. The second option is the CHP based on a regenerative gas turbine engine fueled by neat methanol. The third option is the CHP based on a regenerative gas turbine engine with thermo-chemical recuperation fueled by neat methanol.

According to our calculations, the thermal power of the boiler ranges from 2018 to $4393 \mathrm{~kW}$ (Table 4). The regenerative gas turbine engine with thermo-chemical recuperation has the least thermal power. If the engine is running on methanol (no thermo-chemical recuperation), it has the biggest thermal power. Therefore, consumers may choose the option of a gas turbine plant. 
Table 4. Thermal power of waste heat recovery boiler.

\begin{tabular}{lcccc}
\hline \multicolumn{1}{c}{ Parameters } & Unit & MGO & Methanol & Methanol (Recuperation) \\
\hline Rated power of the gas turbine & $\mathrm{kW}$ & 3400 & 3400 & 3400 \\
Air-flow & $\mathrm{kg} / \mathrm{s}$ & 16 & 16 & 16 \\
Engine efficiency & $\%$ & 38 & 38 & 42 \\
Specific fuel consumption & $\mathrm{g} / \mathrm{kWh}$ & 222,910 & 481,631 & 435,761 \\
Fuel consumption & $\mathrm{kg} / \mathrm{h}$ & 757,895 & $1,637,546$ & $1,481,589$ \\
& $\mathrm{~kg} / \mathrm{s}$ & 0.211 & 0.455 & 0.412 \\
Water flow & $\mathrm{kg} / \mathrm{s}$ & 0 & 0 & 0.69 \\
Exhaust gas temperature & $\mathrm{K}$ & 600 & 600 & 451 \\
Outlet boiler temperature & $\mathrm{K}$ & 438 & 333 & 333 \\
Thermal power & $\mathrm{kW}$ & 2626.11 & 4393.45 & 2017.98 \\
\hline
\end{tabular}

A comparison of the two options (second and third) for cogeneration plants is of theoretical and practical interest. The third option has $9.5 \%$ less methanol consumption, but the second option generates $117 \%$ more thermal power. The second option is preferable if the cost of excess thermal energy is greater than the difference in fuel costs of these options. The second option is preferable if the following expression is true

$$
\xi \cdot\left(Q_{2}-Q_{3}\right) \cdot T h p r \cdot \tau_{t}>\left(G F_{2}-G F_{3}\right) \cdot F p r \cdot \tau_{e}, \mathrm{USD},
$$

where $Q_{2}$ is the thermal power for the second option, $\mathrm{kW} ; Q_{3}$ is the thermal power for the third option, $\mathrm{kW} ;$. Thpr is the thermal power price, USD/kWh; $\tau_{t}$ is the annual time of thermal power production, $\mathrm{h}$; $\tau_{e}$ is the annual time of electricity production, $\mathrm{h} ; G F_{2}$ is the fuel consumption for the second option, $\mathrm{kg} / \mathrm{h} ; G F_{3}$ is the fuel consumption for the third option, $\mathrm{kg} / \mathrm{h} ; \xi$ is the load factor.

After transformation, we get the following expression

$$
\frac{\tau_{t}}{\tau_{e}}>\frac{\left(G F_{2}-G F_{3}\right) \cdot F p r}{\xi \cdot\left(Q_{2}-Q_{3}\right) \cdot T h p r} .
$$

In our calculations for the base case, we assumed the following prices: methanol- $0.28 \mathrm{USD} / \mathrm{kg}$; the thermal power price-0.05 USD $/ \mathrm{kWh}[86]$.

We assumed the price ratio of 4 (taking into account prices as at December 2019). The maximum methanol price in 2019 was assumed to calculate the maximum price ratio of 7 . We assumed the following initial data to study the time ratio:

- the load factor was varied from $60 \%$ to $100 \%$;

- the price ratios were assumed of 4, 5.6 (the base case), and 7 .

The time ratios are presented in Figure 11. An increase in the load factor and a decrease of the methanol/thermal power ratio result in a decrease of the time ratio. At $100 \%$ load, for the base case the time ratio is equal to 0.5 . In other words, the exhaust gas boiler operating hours must be at least $50 \%$ of a gas turbine plant's operating hours. The decrease of the load factor results in an increase in the time ratio.

Therefore, the second option is preferable if consumers of heat energy provide at least $80 \%$ of the loading in the heat recovery system for at least $60 \%$ of the annual operating time. Otherwise, the use of an engine with thermo-chemical recuperation is the best choice. 


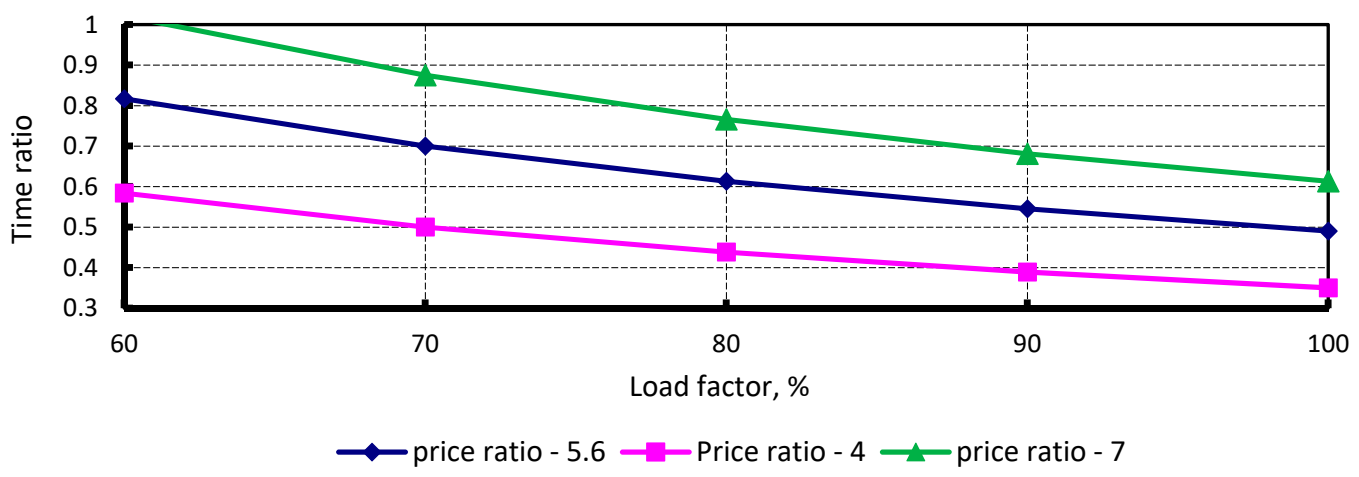

Figure 11. The annual time of thermal power to electricity production ratio.

\section{Conclusions}

Waste heat chemical recuperation of an alcohol regenerative gas turbine engine was studied. It was established that steam methanol conversion at low pressures (around atmospheric pressure) increases the energy consumption of syngas compression for injection to the combustor. This results in a leveling of the energy efficiency of steam conversion.

Studies shown that the use of thermo-chemical recuperation leads to an increase in engine efficiency by 3-5\%.

Thermo-chemical recuperation increases engine efficiency by 3-5\%. It results in a decrease in carbon dioxide emission by $9.5 \%$ compared to direct alcohol burning and by $12-13 \%$ compared to direct diesel fuel burning. Biomethanol is a better choice for reducing carbon dioxide emissions.

An ethanol-fueled regenerative gas turbine engine has the best emission parameters. However, thermo-chemical recuperation is impossible due to the exhaust gas temperature being too low for this kind of alcohol.

A technique for determining carbon dioxide emissions is proposed, which takes into account the actual engine efficiency, fuel properties, and life cycle. To estimate the conversion efficiency of steam alcohol reforming, the conversion performance factor was suggested.

Since mid-2019, methanol has been considered as a competitive alternative for MGO.

To improve profitability, exhaust gas boilers may be used. The methodology for choosing the optimal gas turbine engine (regenerative or regenerative with thermo-chemical recuperation) for a cogeneration unit was proposed.

For an economic comparison of fuels, we have proposed the use of a new indicator-the electricity production from fuel bought for a unit of money.

In further works, alcohol steam recuperation for STIG gas turbine engines will be analyzed. The development of efficient optimal thermo-chemical recuperation will be the subject of study. The economics of alcohol-fueled gas turbine engines are of practical interest. To investigate the behavior of the energy system, neuro-fuzzy technologies are planned to be used in order to determine the optimal parameters and operating modes of the system [89].

Author Contributions: Formal analysis, methodology O.C., V.H., V.S., and A.K.; Investigation, G.M. and J.N.; Writing-original draft, V.H. and A.K.; Writing-review and editing, V.H. and A.K. All authors have read and agreed to the published version of the manuscript.

Funding: This research received no external funding.

Conflicts of Interest: The authors declare no conflict of interest. 


\section{References}

1. BP Energy Outlook: 2019 Edition. Available online: https://www.bp.com/content/dam/bp/businesssites/en/global/corporate/pdfs/energy-economics/energy-outlook/bp-energy-outlook-2019.pdf (accessed on 20 January 2020).

2. Yoon, S.K.; Kim, M.S.; Kim, H.J.; Choi, N.J. Effects of canola oil biodiesel fuel blends on combustion, performance, and emissions reduction in a common rail diesel engine. Energies 2014, 7, 8132-8149. [CrossRef]

3. Qasim, M.; Ansari, T.M.; Hussain, M. Combustion, performance, and emission evaluation of a diesel engine with biodiesel like fuel blends derived from a mixture of Pakistani waste canola and waste transformer oils. Energies 2017, 10, 1023. [CrossRef]

4. Chen, Z.; Yao, C.; Wang, Q.; Han, G.; Dou, Z.; Wei, H.; Wang, B.; Liu, M.; Wu, T. Study of cylinder-to-cylinder variation in a diesel engine fueled with diesel/methanol dual fuel. Fuel 2016, 170, 67-76. [CrossRef]

5. European Union. Directive 2009/28/EC of the European Parliament and of the Council, 23 April 2009. Available online: http://eur-lex.europa.eu/legal-content/PL/ALL/?uri=celex\%3A32009L0028/ (accessed on 12 January 2020).

6. IMO Train the Trainer (TTT) Course on Energy Efficient Ship Operation. Module 2-Ship Energy Efficiency Regulations and Related Guidelines. 2016. Available online: http://www.imo.org/en/OurWork/Environment/ PollutionPrevention/AirPollution/Pages/IMO-Train-the-Trainer-Course.aspx (accessed on 20 January 2020).

7. IPCC - Intergovernmental Panel on Climate Change. Fourth Assessment Report; UN IPCC: Geneva, Switzerland, 2007; Available online: https://www.ipcc.ch/assessment-report/ar4/ (accessed on 20 January 2020).

8. Remme, U. Energy Technology Perspectives 2010: Scenarios \& Strategies to 2050; OECD/IEA: Paris, France, 2010.

9. Ge, J.C.; Kim, M.S.; Yoon, S.K.; Choi, N.J. Effects of pilot injection timing and EGR on combustion, performance and exhaust emissions in a common rail diesel engine fueled with a canola oil biodiesel-diesel blend. Energies 2015, 8, 7312-7325. [CrossRef]

10. Atmanli, A.; Yilmaz, N. A comparative analysis of n-butanol/diesel and 1-pentanol/diesel blends in a compression ignition engine. Fuel 2018, 234, 161-169. [CrossRef]

11. Yilmaz, N.; Atmanli, A.; Vigil, F.M. Quaternary blends of diesel, biodiesel, higher alcohols and vegetable oil in a compression ignition engine. Fuel 2018, 212, 462-469. [CrossRef]

12. Tutak, W.; Jamrozik, A.; Pyrc, M.; Sobiepanski, M. Investigation on combustion process and emissions characteristic in direct injection diesel engine powered by wet ethanol using blend mode. Fuel Process. Technol. 2016, 149, 86-95. [CrossRef]

13. Tutak, W.; Jamrozik, A.; Pyrc, M.; Sobiepanski, M. A comparative study of co-combustion process of diesel-ethanol and biodiesel-ethanol blends in the direct injection diesel engine. Appl. Therm. Eng. 2017, 117, 155-163. [CrossRef]

14. Kuszewski, H. Experimental investigation of the effect of ambient gas temperature on the auto-ignition properties of ethanol-diesel fuel blends. Fuel 2018, 214, 26-38. [CrossRef]

15. Tutak, W.; Lukács, K.; Szwaja, S.; Bereczky, Á. Alcohol-diesel fuel combustion in the compression ignition engine. Fuel 2015, 154, 196-206. [CrossRef]

16. Tutak, W. Bioethanol E85 as a fuel for dual fuel diesel engine. Energy Convers. Manag. 2014, 86, 39-48. [CrossRef]

17. Poran, A.; Tartakovsky, L. Energy efficiency of a direct injection internal combustion engine with high-pressure methanol steam reforming. Energy 2015, 88, 506-514. [CrossRef]

18. Cherednichenko, O.; Serbin, S. Analysis of Efficiency of the Ship Propulsion System with Thermochemical Recuperation of Waste Heat. J. Mar. Sci. Appl. 2018, 17, 122-130. [CrossRef]

19. Cherednichenko, O. Analysis of efficiency of diesel-gas turbine power plant with thermo-chemical heat recovery. MOTROL Comm. Mot. Energ. Agric. 2015, 17, 25-28.

20. Matveev, I.; Serbin, S. Investigation of a reverse-vortex plasma assisted combustion system. In Proceedings of the ASME 2012 Heat Transfer Summer Conference, Rio Grande, Puerto Rico, USA, 8-12 July 2012; pp. $133-140$. [CrossRef]

21. Serbin, S. Features of liquid-fuel plasma-chemical gasification for diesel engines. IEEE Trans. Plasma Sci. 2006, 34, 2488-2496. [CrossRef]

22. Serbin, S.I.; Matveev, I.B.; Goncharova, M.A. Plasma Assisted Reforming of Natural Gas for GTL. Part I. IEEE Trans. Plasma Sci. 2014, 42, 3896-3900. [CrossRef] 
23. Chakravarthy, V.K.; Daw, C.S.; Pihl, J.A.; Conklin, J.C. Study of the theoretical potential of thermochemical exhaust heat recuperation for internal combustion engines. Energy Fuels 2010, 24, 1529-1537. [CrossRef]

24. Tartakovsky, L.; Baibikov, V.; Gutman, M.; Mosyak, A.; Veinblat, M. Performance Analysis of SI Engine Fuelled by Ethanol Steam Reforming Products; 2011-01-1992; SAE Technical Paper: Warrendale, PA, USA, 2011. [CrossRef]

25. Tlili, I.; Hamadneh, N.; Khan, W.A. Thermodynamic analysis of MHD heat and mass transfer of nanofluids past a static wedge with Navier slip and convective boundary conditions. Arab. J. Sci. Eng. 2019, 44, 1255-1267. [CrossRef]

26. Khan, M.N.; Tlili, I.; Khan, W.A. Thermodynamic optimization of new combined gas/steam power cycles with HRSG and heat exchanger. Arab. J. Sci. Eng. 2017, 42, 4547-4558. [CrossRef]

27. Khan, M.N.; Khan, W.A.; Tlili, I. Forced convection of nanofluid flow across horizontal elliptical cylinder with constant heat flux boundary condition. J. Nanofluids 2019, 8, 386-393. [CrossRef]

28. Gonca, G. The effects of turbine design parameters on the thermo-ecologic performance of a regenerated gas turbine running with different fuel kinds. Appl. Therm. Eng. 2018, 137, 419-429. [CrossRef]

29. Musmar, S.A.; Razavinia, N.; Mucciardi, F.; Tlili, I. Performance analysis of a new waste heat recovery system. Int. J. Therm. Environ. Eng. 2016, 12, 47-52. [CrossRef]

30. Wahab, A.; Ibrahim, T. The effects of the temperatures on the performance of the gas turbine. In The Latest Methods of Construction Design; Springer: Berlin, Germany, 2016; pp. 185-193. [CrossRef]

31. Jin, H.; Zhang, X.; Hong, H.; Han, W. An Innovative Gas Turbine Cycle with Methanol-Fueled Chemical-Looping Combustion. J. Eng. Gas Turbines Power 2009, 131, 061701. [CrossRef]

32. Pan, F.; Zheng, H.; Liu, Q.; Yang, R. Design and performance calculations of chemically recuperated gas turbine on ship. Proc. Inst. Mech. Eng. Part A J. Power Energy 2013, 227, 908-918. [CrossRef]

33. Al-Saraf, A.S.J.; Al-Jumaily, S.A.R. The Power Enhancement of a Mini-Gas Turbine by Adding Ethanol to the Compressor Inlet Air. Al-Khwarizmi Eng. J. 2013, 9, 54-64.

34. Ethanol Power Plant, Minas Gerais. 21 January 2010. Available online: https://www.power-technology.com/ projects/ethanol-power-plant/ (accessed on 21 January 2020).

35. Moliere, M.; Vierling, M.; Aboujaib, M.; Patil, P.; Eranki, A.; Campbell, A. Gas Turbines in Alternative Fuel Applications: Bio-Ethanol Field Test. In Proceedings of the ASME Turbo Expo 2009: Power for Land, Sea, and Air, Orlando, FL, USA, 8-12 June 2009. [CrossRef]

36. Eilat Power Plant, Unit No. 3 Preliminary Report GT Performance with Methanol Firing After Retrofit. Preliminary Report. Eilat Power Plant. April 2014. Available online: https:/g2xenergy.com/images/ downloads/eilat-simple-cycle-pratt-and-whitney-ft4c.pdf (accessed on 21 January 2020).

37. Kalinichenko, A.; Havrysh, V.; Atamanyuk, I. The Acceptable Alternative Vehicle Fuel Price. Energies 2019, 12, 3889. [CrossRef]

38. Tartakovsky, L.; Baibikov, V.; Veinblat, M. Comparative Performance Analysis of SI Engine Fed by Ethanol and Methanol Reforming Products; 2013-01-2617; SAE Technical Paper: Warrendale, PA, USA, 2013. [CrossRef]

39. Choi, K.S.; Kim, H.M.; Dorr, J.L.; Yoon, H.C.; Erickson, P.A. Equilibrium model validation through the experiments of methanol autothermal reformation. Int. J. Hydrog. Energy 2008, 33, 7039-7047. [CrossRef]

40. Stamatis, A.; Vinni, C.; Bakalis, D.; Tzorbatzoglou, F.; Tsiakaras, P. Exergy Analysis of an Intermediate Temperature Solid Oxide Fuel Cell-Gas Turbine Hybrid System Fed with Ethanol. Energies 2012, 5, 4268-4287. [CrossRef]

41. Kandepu, R.; Imsland, L.; Foss, B.A.; Stiller, C.; Thorud, B.; Bolland, O. Modeling and control of a SOFC-GT-based autonomous power system. Energy 2007, 32, 406-417. [CrossRef]

42. Haseli, Y.; Dincer, I.; Naterer, G.F. Thermodynamic analysis of a combined gas turbine power system with a solid oxide fuel cell through exergy. Thermochim. Acta 2008, 480, 1-9. [CrossRef]

43. Carapellucci, R. A unified approach to assess performance of different techniques for recovering exhaust heat from gas turbines. Energy Convers. Manag. 2009, 50, 1218-1226. [CrossRef]

44. Cocco, D.; Tola, V.; Cau, G. Performance evaluation of chemically recuperated gas turbine (CRGT) power plants fuelled by di-methyl-ether (DME). Energy 2006, 31, 1446-1458. [CrossRef]

45. Verkhivker, G.; Kravchenko, V. The use of chemical recuperation of heat in a power plant. Energy 2004, 29, 379-388. [CrossRef]

46. Sá, S.; Sousa, J.M.; Mendes, A. Steam reforming of methanol over a CuO/ZnO/A12O3 catalyst part II: A carbon membrane reactor. Chem. Eng. Sci. 2011, 66, 5523-5530. [CrossRef] 
47. Mingheng, L.; Duraiswamy, K.; Knobbe, M. Adsorption enhanced steam reforming of methanol for hydrogen generation in conjunction with fuel cell: Process design and reactor dynamics. Chem. Eng. Sci. 2012, 67, 26-33. [CrossRef]

48. Sá, S.; Silva, H.; Brandão, L.; Sousa, J.M.; Mendes, A. Catalysts for methanol steam reforming-A review. Appl. Catal. B Environ. 2010, 99, 43-57. [CrossRef]

49. Casanovas, A.; Divins, N.J.; Rejas, A.; Bosch, R.; Llorca, J. Finding a suitable catalyst for on-board ethanol reforming using exhaust heat from an internal combustion engine. Int. J. Hydrog. Energy 2017, 42, 13681-13690. [CrossRef]

50. Tartakovsky, L.; Baibikov, V.; Veinblat, M. Modeling Methanol Steam Reforming for Internal Combustion Engine. Energy Power 2014, 4, 50-56. [CrossRef]

51. We Power the World with Innovative Gas Turbines. Siemens Gas Turbine Portfolio. Available online: https://assets.new.siemens.com/siemens/assets/api/uuid:10f4860b140b2456f05d32629d8d758dc00bcc30/gasturbines-siemens-interactive.pdf (accessed on 23 January 2020).

52. Gas Turbine Engines for Gas Pipelines. Zorya-Mashproekt. Available online: https://www.epicos.com/sites/ default/files//gas_turbine_engines_for_gas_pipelines.pdf (accessed on 23 January 2020).

53. Kawasaki Gas Turbine Generator Sets. Available online: https:/global.kawasaki.com/en/energy/pdf/Green Brochure.pdf (accessed on 23 January 2020).

54. Mercury 50. Recuperated Gas Turbine Generator Set. Available online: http://s7d2.scene7.com/is/content/ Caterpillar/CM20150710-52396-21070 (accessed on 23 January 2020).

55. Colin, R. The WR-21 Intercooled Recuperated Gas Turbine Engine-Integration into Future Warships. In Proceedings of the International Gas Turbine Congress 2003, Tokyo, Japan, 2-7 November 2003. Available online: https:/nippon.zaidan.info/seikabutsu/2003/00916/pdf/igtc2003tokyo_os203.pdf (accessed on 23 January 2020).

56. Matveev, I.; Waschilenko, N.; Serbin, S.; Goncharova, N. Integrated Plasma Coal Gasification Power Plant. IEEE Trans. Plasma Sci. 2013, 41, 3195-3200. [CrossRef]

57. Cengel, Y.A.; Boles, A.M. Thermodynamics: An Engineering Approach, 8th ed.; McGraw-Hill: New York, NY, USA, 2015.

58. Poran, A.; Tartakovsky, L. Influence of methanol reformate injection strategy on performance, available exhaust gas enthalpy and emissions of a direct-injection spark ignition engine. Int. J. Hydrog. Energy 2017, 42, 15652-15668. [CrossRef]

59. Hoffman, W.; Wong, V.; Cheng, W. A New Approach to Ethanol Utilization: High Effciency and Low NOx in an Engine Operating on Simulated Reformed Ethano; 2008-01-2415; SAE Technical Paper: Warrendale, PA, USA, 2008. [CrossRef]

60. Ma, H.; Zhang, R.; Huang, S.; Chen, W.; Shi, Q. Ni/ $\mathrm{Y}_{2} \mathrm{O}_{3}-\mathrm{Al}_{2} \mathrm{O}_{3}$ catalysts for hydrogen production from steam reforming of ethanol at low temperature. J. Rare Earths 2012, 30, 683-690. [CrossRef]

61. Zhang, B.; Cai, W.; Li, Y.; Xu, Y.; Shen, W. Hydrogen production by steam reforming of ethanol over an $\mathrm{Ir} / \mathrm{CeO}_{2}$ catalyst: Reaction mechanism and stability of the catalyst. Int. J. Hydrog. Energy 2008, 33, 4377-4386. [CrossRef]

62. Fayyazbakhsh, A.; Pirouzfar, V. Comprehensive overview on diesel additives to reduce emissions, enhance fuel properties and improve engine performance. Renew. Sustain. Energy Rev. 2017, 74, 891-901. [CrossRef]

63. Yusri, I.M.; Mamat, R.; Najafi, G.; Razman, A.; Awad, O.I.; Azmi, W.H.; Ishak, W.F.W.; Shaiful, A.I.M. Alcohol based automotive fuels from first four alcohol family in compression and spark ignition engine: A review on engine performance and exhaust emissions. Renew. Sustain. Energy Rev. 2017, 77, 169-181. [CrossRef]

64. Kumar, M.S.; Nataraj, G.; Arulselvan, S. A comprehensive assessment on the effect of high octane fuels induction on engine's combustion behaviour of a Mahua oil based dual fuel engine. Fuel 2017, 199, $176-184$. [CrossRef]

65. Yates, A.; Bell, A.; Swarts, A. Insights relating to the autoignition characteristics of alcohol fuels. Fuel 2010, 89, 83-93. [CrossRef]

66. Goncharuk, A.G.; Havrysh, V.I.; Nitsenko, V.S. National features for alternative motor fuels market. Int. J. Energy Technol. Policy 2018, 14, 226-249. [CrossRef] 
67. LNG Carriers with ME-GI Engine and-High Pressure Gas Supply System. MAN Diesel \& Turbo. 5510-0026-04ppr September 2014. Available online: https://marine.mandieselturbo.com/docs/ librariesprovider6/technical-papers/lng-carriers-with-high-pressure-gas-supply-system.pdf?sfvrsn=16 (accessed on 23 January 2020).

68. Tartakovsky, L.; Sheintuch, M. Fuel reforming in internal combustion engines. Prog. Energy Combust. Sci. 2018, 67, 88-114. [CrossRef]

69. Poran, A.; Tartakovsky, L. Performance and emissions of a direct injection internal combustion engine devised for joint operation with a high-pressure thermochemical recuperation system. Energy 2017, 124, 214-226. [CrossRef]

70. Larfeldt, J.; Andersson, M.; Larsson, A.; Moell, D. Hydrogen Co-Firing in Siemens Low NOx Industrial Gas Turbines. In Proceedings of the POWER-GEN Europe, Cologne, Germany, 27-29 June 2017. Available online: https://pdfs.semanticscholar.org/37fd/8e07212bf1e60f6db535d6e422b11880b816.pdf (accessed on 23 January 2020).

71. Bancalari, E.; Chan, P.; Diakunchak, I.S. Advanced Hydrogen Gas Turbine Development Program. In Proceedings of the ASME Turbo Expo 2007: Power for Land, Sea, and Air, Montreal, QC, Canada, 14-17 May 2007; Volume 2: Turbo Expo 2007, pp. 977-987. [CrossRef]

72. Nose, M.; Kawakami, T.; Araki, H.; Senba, N.; Tanimura, S. Hydrogen-fired Gas Turbine Targeting Realization of $\mathrm{CO}_{2}$-free Society. Mitsubishi Heavy Ind. Technol. Rev. 2018, 55, 1-7.

73. Larfeldt, J. Applying Simulation and Additive Manufacturing to the Development of Next Generation of Hydrogen Combustion. 2017. Available online: http://www.international-bc-online.org/wp-content/ uploads/2018/04/2_-Hydrogen_cofiring_Larfeldt_13april2018.pdf (accessed on 23 January 2020).

74. ANSYS. Chemkin Theory Manual 17.0. Reaction Design. 2016. Available online: https://www.ems.psu.edu/ $\sim\{\}$ radovic/ChemKin_Theory_PaSR.pdf (accessed on 23 January 2020).

75. Gagliano, A.; Nocera, F.; Bruno, M.; Cardillo, G. Development of an equilibrium-based model of gasification of biomass by Aspen Plus. Energy Procedia 2017, 111, 1010-1019. [CrossRef]

76. Cherednichenko, O.K. Peculiarities of application of methanol conversion products in a ship gas turbine plants with thermochemical regeneration of waste heat. Aerosp. Eng. Technol. 2019, 3, 28-34. [CrossRef]

77. Havrysh, V.; Kalinichenko, A.; Hruban, V. Heat Recovery Systems for Agricultural Vehicles: UtilizationWays and Their Efficiency. Agriculture 2018, 8, 199. [CrossRef]

78. Eriksson, M.; Ahlgren, S. LCAs of Petrol and Diesel-A Literature Review; Swedish University of Agricultural Science: Uppsala, Sweden, 2013. Available online: https://pub.epsilon.slu.se/10424/17/ahlgren_s_and_ eriksson_m_130529.pdf (accessed on 12 February 2020).

79. Gupta, P.; Zhuge, W.; Luo, S.; Ma, F. The well-to-wheel analysis of hydrogen enriched compressed natural gas for heavy-duty vehicles using life cycle approach to a fuel cycle. Int. J. Low-Carbon Technol. 2019, 14, 432-439. [CrossRef]

80. Roman-White, S.; Rai, S.; Littlefield, J.; Cooney, G.; Skone, T.J. Life Cycle Greenhouse Gas Perspective on Exporting Liquefied Natural Gas from the United States: 2019 Update; National Energy Technology Laboratory: Pittsburgh, PA, USA, 2019.

81. Ingham, A. Reducing the Carbon Intensity of Methanol for Use as a Transport Fuel. Johns. Matthey Technol. Rev. 2017, 61, 297-307. [CrossRef]

82. Kajaste, R.; Hurme, M.; Oinas, P. Methanol-Managing greenhouse gas emissions in the production chain by optimizing the resource base. AIMS Energy 2018, 6, 1074-1102. [CrossRef]

83. Kumar, D.; Murthy, G.S. Life cycle assessment of energy and GHG emissions during ethanol production from grass straws using various pretreatment processes. Int. J. Life Cycle Assess. 2012, 17, 388-401. [CrossRef]

84. ADI Analytics, Energy Insight and Consulting. Methanol for Power Generation: A White Paper; ADI Analytics, Energy Insight and Consulting: Katy, TX, USA, 2017.

85. Kalinichenko, A.; Havrysh, V. Environmentally Friendly Fuel Usage: Economic Margin of Feasibility. Ecol. Chem. Eng. S 2019, 26, 241-254. [CrossRef]

86. Global Average Bunker Price. Available online: https://shipandbunker.com/prices/av/global/av-glb-globalaverage-bunker-price\#MGO (accessed on 10 February 2020).

87. Methanex Posts Regional Contract Methanol Prices for North America, Europe and Asia. Available online: https://www.methanex.com/our-business/pricing (accessed on 10 February 2020). 
88. Balussou, D. An Analysis of Current and Future Electricity Production from Biogas in Germany. Ph.D. Thesis, Karlsruhe Institute of Technology, Karlsruhe, Germany, 2018. Available online: https://publikationen. bibliothek.kit.edu/1000084909 (accessed on 12 February 2020).

89. Kondratenko, Y.P.; Kozlov, O.V.; Kondratenko, G.V.; Atamanyuk, I.P. Mathematical Model and Parametrical Identification of Ecopyrogenesis Plant Based on Soft Computing Techniques. In Complex Systems: Solutions and Challenges in Economics, Management and Engineering; Berger-Vachon, C., Gil Lafuente, A., Kacprzyk, J., Kondratenko, Y., Merigó, J., Morabito, C., Eds.; Springer: Cham, Switzerland, 2018; Volume 125, pp. 201-233. [CrossRef]

(C) 2020 by the authors. Licensee MDPI, Basel, Switzerland. This article is an open access article distributed under the terms and conditions of the Creative Commons Attribution (CC BY) license (http://creativecommons.org/licenses/by/4.0/). 